theories and

methodologies

\section{The Case of Lady Anne Clifford; or, Did Women Have a Mixed Monarchy?}

\author{
JULIE CRAWFORD
}

JULIE CRAWFORD, associate professor of English literature at Simon Fraser University, is the author of Marvelous Protestantism: Monstrous Births in Post-Reformation England (Johns Hopkins UP, 2005) and numerous articles on early modern literature and culture. She is completing a book on women and the production of coterie literature in early modern England.
I BECAME A FEMINIST CRITIC OF THE RENAISSANCE IN 1989, WHEN A PROFESSOR, IN ANSWER TO MY QUESTION ABOUT WHY THERE WERE NO WOMEN

on the syllabus, replied that there were no women writers in the seventeenth century. This comment took me to the library, where I discovered what he should have known but did not have to: not only were there women writers in the period, but feminist literary critics were retrieving them from the archives and rewriting literary history in the light of their contributions. One of these women writers was Lady Anne Clifford (1590-1676), the author of a singularly massive amount of genealogical, historical, and personal writings and a subject of interest, long before the 1980s, for Vita Sackville-West and Virginia Woolf. In 1985, the Marxist feminist critic Katharine Hodgkin wrote an essay about Clifford's conflicted status as a woman (victim of patriarchy) and as a landlord (oppressor). Clifford has received different treatment in recent years, considered primarily as a diarist (with the attendant and often ahistorical assumptions the genre solicits [see Kunin]) and as a heroic resister of patriarchal forces. My goal here is to use Clifford as a case study for the role of feminist criticism today, not only because she has raised such complex issues for feminist critics of the Renaissance and early modern period but also because the issues her life and work raise about kinship and the household, property and political agency, and the intersectionality of determining forces of identity and power are of continuing relevance to feminist methodologies and politics. I am particularly concerned with feminist claims that have become axiomatic-for the early modern period as well as others-both at the level of historical progression (the march toward modernity) and in more synchronic analyses of social and cultural practices and relationships (including our assumptions that we know what patriarchy, kinship, and household mean). By unsettling these axioms and reconsidering the stories Clifford tells, I hope to illustrate the truth that feminist criticism is by its nature a reconsideration, a form of doing rather than being.

In her memoir for the year 1603, Clifford writes that after being exposed to the plague, "my Coz. Frances [Bourchier] got the Key of

(C) 2006 BY The MOdern LANGUAge association of America] 
my Chamber \& lay with me which was the first time I loved her so very well" (qtd. in Acheson 8). During some of the battles she fought over the Clifford family land in the years 161619. Clifford made a somewhat different series of bedchamber observations about her husband, Richard Sackville, third earl of Dorset, who wanted her to take a cash settlement instead of continuing her battle over what she considered to be her inalienable property rights to the barony of Westmorland. ${ }^{1}$ In a diary entry Clifford notes that after a series of battles about the case, her lord gave up his habit of sleeping separately from her and with his favorite retainer, Matthew Caldicott, and "came to Lye in my chamber" (80). ${ }^{2}$ As Michael Lucey has recently reminded us, sexuality can be a "ruse of inheritance structures" rather than an expression of desire, "part of a template that brings affect, family, and certain channels of inheritance" into proximity (150). Indeed, I want to suggest that both examples of bedroom intimacy cited above need to be thought about less in terms of sexuality than in terms of kinship-the presumptive heterosexuality of which Judith Butler has recently questioned ("Is Kinship")—and of property, or what Lucey calls "inheritance structures."3 Clifford understood kinship neither in terms of heterosexuality nor, more accurately, in terms of horizontal or matrimonial alliance but rather in terms of lineal inheritance: Frances Bourchier was her cousin, Dorset merely her husband. (Indeed, while Dorset's death solicits minimal commemoration from Clifford, Bourchier's merits the establishment of a monument in the Russell family church [Spence, Lady Anne Clifford 67]). ${ }^{4}$ I juxtapose these scenes of intimacy to highlight the fact that Clifford's ideas of kinship and property trouble our ideas about women's public and private roles in the sixteenth and seventeenth centuries and thus encourage us to question our assumptions about women's agency in the period now known as the early modern. ${ }^{5}$

Maureen Quilligan has recently illuminated the extent to which what we might call extreme kinship, or incest, was a way of keeping property in the family, particularly for women (Incest). At the 2006 Renaissance Society of America Conference, Quilligan returned to Joan Kelly's famous question, "Did women have a Renaissance?" through the issue of royal women's dynastic routes to and maintenance of power. Quilligan sees this power as a specifically Renaissance phenomenon often opposed, as it was for Elizabeth I, by male republican and thus protomodern criticism and resistance. In contradistinction to Kelly's argument that women did not have a Renaissance, Quilligan suggests that some women did and, moreover, that it was a specifically Renaissance, not early modern, phenomenon ("Reperiodizing"). What I discuss here is the extent to which some other women, exemplified by the eminently aristocratic Clifford, may well have had a Renaissance, but it was a Renaissance that looked a lot like feudalism. Yet instead of seeing Clifford as merely hanging onto values inevitably lost in the "great transition" from feudalism to the modern state, or indeed from the "open lineage" to "restricted patriarchal family" (Stone), I look at the ways in which Clifford used her pursuit of her baronial status, and her diary's strategically political recording of this pursuit, as a pointed reminder of England's status as a mixed rather than absolutist monarchy. ${ }^{6}$ Thus while I make an argument for Clifford's active political role, it is not an agency predicated on individualism, either as an accurate description of the nature of her power or as a feminist end in itself. ${ }^{7}$ Moreover, I see Clifford, like Margaret Cavendish (Crawford), as modeling her authority not on an absolutist model-what Catherine Gallagher identified as the royalist woman writer's moi absolu-but rather on other models of power based on the offices of land and lineage and the key, if underrecognized, role such offices played in Tudor and Stuart politics and culture. Finally, while I do want to suggest that propertied women had a mixed monarchy, or, more precisely, an active 
political role in sixteenth- and seventeenthcentury England that ahistorical accounts of women's roles in the household, family, and the domestic erase, I do not want to suggest that this political agency was early modern or protorepublican in some progressive sense. Indeed, while my argument about the nature of Clifford's power asks us to be critical of how we accept the patriarchal ideology of the Jacobean monarchy and the patriarchally conscribed familial, domestic, and household roles of women in the period, it also asks us to be critically aware of the extent to which this power relied, substantively, on the subordination and labor of others. ${ }^{8}$

During her negotiations with her husband and the Crown over her rights to the Westmorland estates, Clifford records in her diary a moment at which "men of note," including the archbishop of Canterbury, "were all in the Gallery at Dorset House," her husband's chief seat (qtd. in Acheson 10). She, meanwhile, is sent north to her mother, Margaret Clifford, countess of Cumberland, currently enacting her jointure rights on the Westmorland estates (on Margaret's tenure in the north, see Spence, Lady Anne Clifford, ch. 2). Clifford notes that " $[\mathrm{u}]$ pon the $22^{\text {nd }}$ my Lady \& I went in a Coach together to Whinfield \& ridd about the Park \& saw all the woods" and on "Easter day" received together "in the chapel at Broome [Brougham]" (43). While Clifford presents Dorset House as a site of her husband's politico-economic machinations-he would pocket the cash settlement offered in lieu of her inheritance rights-Westmorland is a wholly different arena in which Clifford plays a resolutely public, liveried, and baronial role. (Indeed, after her mother's death, Clifford further entrenches her office by encouraging the tenants to "keepe the money in their own hands till it were known who had a right to it" [56], an active sign of resistance to her uncle's seigneurial rights). ${ }^{9}$ Conversely, while at Knole, the Sackville property at which she lived during much of her mar- riage, Clifford records her performance of a different role, the pietistic wife of domestic conduct books. On another Easter she records reading the Bible and "a book of the preparation to the sacrament" and appearing "to her lord" "in white satten gown \& white waist coat" (80). The point I want to make here is not, as Mary Ellen Lamb has argued, that Clifford suffered from a split subjectivity or even that she inhabited or lived different roles. Rather, each entry is a record with political intentions, the scripts not of patriarchy on one hand and property on the other but of the ways in which Clifford self-consciously performed "wife" often in subtle and indirect support of her pursuit and performance of her office as rightful baron of Westmorland (Chan and Wright). ${ }^{10}$ Clifford thus frequently presents her life at Knole not as a narrative of wifely subservience but as a negotiation between two modes of inheritance-lineal and marital-and between two ways of enacting and promoting aristocratic entitlement. ${ }^{11}$

While Clifford is highly conscious of the roles she must play on the varied stages of early Jacobean aristocratic life, she is equally conscious of how she represents her husband in her diary. While most readers of the diary note that Clifford presents her husband in a negative light, I suggest that these representations are less a description of a personal battle, or even criticism of Dorset per se, than a political indictment of a specific form of courtiership. Indeed, both Lawrence Stone and Kelly see the role of the courtier (particularly in Castiglione's version, translated into English in 1561) as intimately related to the diminishing power of the landholding aristocracy in the move toward the modern state and to the profound divisions between men and women in the period. (Kelly suggests that domestic patriarchy was something of a consolation prize for the lord's diminished power in the political realm and its purchase the grounds for her insistence that women, or at the very least Italian noblewomen, did not have a Renaissance.) 
Clifford records that while Dorset was in London-which, as one of James I's favorites, he often was- "he went much abroad to Cocking, to bowling Alleys, to Plays \& Horseraces, \& was commended by all the World." She, in contrast, "stay'd in the Country having many times a sorrowfull and heavy heart, and being condemn'd by most folks because I would not consent to the agreements" (48). While many scholars see these lines as testament to her marital oppression and subjection (Barbara Lewalski calls them a "poignant complaint" [149]), I see them as a strategic deployment of the contradictions within Jacobean courtly and political discourse. Clifford casts herself in the role of the (maritally embattled) country house mistress who "dwells," as per the instructions of James I, in the country instead of spending her wealth at court and presents her husband as a frivolous courtier. Yet despite James's investment in country houses as a means of maintaining (his) order in the country, the king was famously invested in his courtiers, whose role in court politics was, as Clifford was well aware, deeply controversial. My argument here is buttressed by Clifford's observation that when Dorset came home from London, her lord "lay in Lester [Leicester's] chamber \& I in my owne” (49). For Clifford, the choice of bedchamber was almost always a symbolic act of remembrance and alliance (see, e.g., 44, 46, 58, 61, 78, 79, 89, 101). Leicester was Elizabeth's chief courtier, attacked by many for his overly influential role as chief counselor. Just as she writes a political script for herself, Clifford writes one for her husband: that of the compromised courtier. In contrast to her husband's petty power brokering and structural subservience, ${ }^{12}$ Clifford notes her own time spent reading, "writing the [family] Chronicles," and praying to "god to send me some end of my troubles, that my Enemys might not still have the upper hand of me" (71). While her husband relies solely on the king and the arts of courtly machination, she relies on lineage and its divine vindication, the aristocratic corollary of the divine right of kings James I so adamantly promoted. ${ }^{13}$

When Clifford eventually goes to London, "every body perswading me to heare $\&$ to make an end since the King had taken the matter in hand," she self-consciously takes up a new "part ... upon the stage of this world" (62). Yet that part is played in Queen Anne's court as well as James's, reminding us that there was no monolithic "patriarchal power structure" in the Jacobean period but rather competing sites of power-marital, lineal, and courtly. Clifford meets with Anne's chief courtiers at Somerset House, the center of Anne's court, twice before she goes to James's (64). In his court, the king is surrounded by his courtiers, including, as Clifford points out, her husband and the newly created earl of Buckingham (64). Clifford implicitly associates her husband with James's increasingly unpopular chief courtier and favorite, Buckingham, who had already come under considerable attack from parliament for his abuse of his position (Lockyer). When summoned before the king not long after, Clifford offers the following account of her visit:

[I] went presently after dinner to the Queen to the drawing Chamber, where my Lady Derby told the Queen how my business stood \& that I was to go to the King, so she promised me she wou'd do all the good in it she could. when I had stay'd but a little while there, I was sent for out my Lord \& I going through my Lord Buckingham's Chamber who brought us into the King being in the drawing Chamber. He put out all that were there \& my Lord \& I kneeled by his chair side when he perswaded us both to peace $\&$ to put the matter wholly into his hands, which my Lord Consented to; but I beseech'd His Majesty to pardon me for that I wou'd never part with Westmorland while I lived upon any Condition Whatsoever. sometimes he used fair means \& perswasions, \& sometimes fowle means but I was resolved before so as nothing wou'd move me.

In this account, Clifford represents her resistance to the king as resolutely principled and 
located in ancient property rights and principles of honor: an aristocratic, indeed feudal, negotiation between powers. In contrast, she represents her husband as obedient, even servile, immediately consenting to "put the matter wholly into [the king's] hands."14

In a way the drama she scripts is a microcosm of the shift that critics who favor either Marxist or patriarchal-monarchical readings of the period propose: the transition from feudalism to the modern state, exemplified by the ways in which landholding aristocrats became court-dependent courtiers, and the rise of an ideology of patriarchy, exemplified by the supplanting of the virgin and dynastic queen by the patriarchal absolutist king. Yet there are a number of details in this remarkable passage that question both the thoroughness of this theorized transition and the comprehensiveness of Jacobean patriarchy. First, Clifford's position was not merely contrary; there were other dynastic and factional forces that habitually challenged and negotiated with the king, not least among them the Sidneys and Herberts. Second, the Jacobean state may have promoted patriarchal values, but it was neither unified nor absolute, as one of Clifford's later marginal notations highlights. The queen, she writes, "gave me warning to take heed of putting my matters absolutely to the King lest he shou'd deceive me" (66). During her visit to London, Clifford makes use of the differing spaces of power-the queen offers advice from her drawing chamber, which Clifford explicitly identifies as countering the power of the king-and notes that the route to the king is directly though his favorite's chamber. There are rival courts, and, like "Lester's room," Buckingham's chamber is a site not of male and public-as opposed to female and private-power but of the corrupt political intimacies and machinations of the courtier. Clifford thus points to her awareness of Queen Anne as another route to power and signals her own investment in the power and importance of the lineal dynasty as opposed to either the marital bond or courtly subservience. She reinforces these values, furthermore, with a remarkable gift, sending the queen "a new years gift of a Cloth of silver Cushion Embroided richly with the King of Denmark's arms" (97). (In addition to being James I's queen consort, Anne of Denmark was the daughter of Frederick II and sister of Christian IV, subsequent kings of Denmark.) In drawing parallels between corrupt courtiers and her husband and between her own lineal and genealogical power base and that of the queen, Clifford explicitly privileges a less-than-absolutist mode of doing politics. ${ }^{15}$

Toward the end of her diary, and still in the midst of the battles over her inheritance, Clifford makes the following entry: "my Lo. Came \& supped with me in my Chamber which he had not done before since his coming from London, for I determined to keep my Chamber \& did not so much as go over the threshold of the door" (120). This threshold crossing is precisely where sexuality is signaled as a ruse of inheritance structures and where Clifford's purportedly private life is heralded as the exact opposite. Her keeping to her "Chamber" emblematizes her separate familial and political fidelities. ${ }^{16}$ On an earlier occasion, Clifford records that while they were fighting over the inheritance in London, her husband brought her cousin (the heir to her father's estates) into her bedchamber "much against my will" to talk about the case (94). As in the earlier episode, her husband's threshold crossing at Knole attests not to some form of romantic making up but to an entrenched pattern of economic and political negotiation, fought, among other places, in the bedroom. The fact that Clifford records it all with such scrupulous care in her diary, always highlighting her own aristocratic and lineal prerogatives, signals the extent to which she was aware not merely of the complex ways in which the power of the aristocracy was being diminished but also of the various means by which these principles could be preserved and promoted. 
Clifford's reliance on and assertion of England's status as a mixed monarchy was a form of political agency deeply concerned with property, lineage, and political representation. It is no coincidence that Clifford turned her attention later in life to rack-renting as well as to electing members of parliament (parliament, despite the matter of the Restoration, was in the ascendancy). Clifford's negotiations between country and court, lineage and marriage, and aristocratic privilege and courtly subservience were undertaken in a context riven by changing ideas of kinship and family, property rights, and political representation at all levels of society, not least by those members who had a great deal to gain from the decline of the aristocracy, whether they were women or not. Her negotiations merit attention not only because, as Butler points out (Antigone's Claim), deeply ideological ideas about kinship structure the distribution of social and economic privileges in the present moment, but also because they underscore the extent to which seemingly axiomatic ideas about women's familial and household roles under an absolutist and patriarchal monarch are predicated on dominant narratives rather than more recent feminist reconsiderations of the nature of political power.

\section{NOTES}

1. Although by common law Clifford could have inherited her father's property, when George Clifford, earl of Cumberland, died in 1605 , he left his property entailed to his brother and his brother's male heirs, a decision Anne and her mother fought, now quite famously, for years. For the details of the case, see Acheson; Spence, Lady Anne Clifford; and Williamson.

2. While Helen Wilcox suggests that Clifford "rejoic[ed] in the occasions" when her husband came to lie in her chamber (58), I see less rejoicing than a detailed recording of their bedroom as a site of negotiation.

3. It is, however, remarkable to me that the same-sex bed sharing of both Clifford and her husband has solicited almost no critical commentary. Barbara Lewalski refers to "a close (perhaps a homosexual) relationship" between Dor- set and "his gentleman-servant Matthew Caldicott" (128), and Jonathan Goldberg $(39,200 \mathrm{n} 27)$ and Valerie Traub (53) briefly refer to Clifford sleeping with her cousin.

4. Clifford was consistently invested in bilateral or cognatic kinship. Samuel Daniel's poem to her, to take only one example, celebrates "the honourable blood / Of Clifford and Russell" (qtd. in Hodgkin 160). George Clifford had been the ward of his future father-in-law, Francis Russell, earl of Bedford, further cementing and complicating Clifford's investment in her cognatic lineage (Spence, Lady Anne Clifford 5).

5. Barbara Lewalski, for example, suggests that Clifford's diary focuses "chiefly on her own doings and family affairs with very sporadic references to public matters," presuming that the two matters-familial and political-are separate (141). Lewalski's suggestion that many of Clifford's diary entries record "quotidian domestic activities" (149) similarly presumes that we always already know what the domestic means, and, moreover, that it is a sphere both banal and apolitical. Olivia Harris, in contrast, reminds scholars of the danger of defining domestic tasks and activities "in such a way as they seem self-evident and universal” (145). (Visiting, one of Lewalski's examples of quotidian domestic activities, is by no means either a universal or an apolitical activity.) By estranging the domestic we can see how it functions politically for Clifford.

6. In his review of The Family: Sex and Marriage in England, 1500-1800, David S. Berkowitz summarizes Lawrence Stone's argument thus: "England during [the period from 1500 to 1800] experiences a transformation from a kinship, group-dominated, estate accumulating, smallscale farming and trading, in-bred, gentry-dominated community to an atomic, autonomous, industrialized wealth-creating and people-exporting society on the verge of dominating world markets as it marched towards parliamentary democracy" (398).

7. In a 1994 essay on early modern women writers, Margaret Ferguson pointed out the necessity of historicizing and examining the "ideological dimension of personal autonomy." Indeed, she points to Lewalski's description of Clifford as a "kind of David taking on the Goliath of the patriarchal power structure" (Lewalski 15l) to highlight the extent to which many critics valorize an ideal of selfconscious individuality. Ferguson, in contrast, argues that Clifford wanted "not to critique that Goliath structure but rather to have a bigger piece of its pie" (361). Ferguson's focus on Clifford's economic ambitions is informative for my argument about Clifford's lineal and political activism.

8. It's interesting to me that the first feminist Marxist account of Clifford's work and life, the work of Katharine Hodgkin, appeared in the same year that Gayatri Chakravorty Spivak's famous essay “Three Women's Texts and a Critique of Imperialism" asked feminist scholars to look at what feminist accounts of women's "individualism" were predicated on and at whose cost. Quilligan is well aware that the switch to the use of "early modern" in discussing 
the period also known as the Renaissance asked us to focus on arenas of culture beyond the classical, elite, and monarchical and thus to question the assumptions of our periodization "Renaissance" and its implicit erasure of gender and class inequalities. Indeed, when Clifford finally achieved her baronial property rights in 1643 , she "lord[ed] it over the North ... from the midst of a little court of her own" (Sackville-West xxxiv, xlv; qtd. in Wiseman 216n60). Her lordship relied on the oppression (including rack-renting) and manipulation of her tenants, a fact that R. T. Spence points out in the Oxford Dictionary of National Biography, even as he celebrates Clifford's “stubbornness about the mouth and chin" (a detail not pointed out about, say, the earl of Pembroke) and the fact that her "regime [was] beneficent, religious, and, in the best sense of the term, baronial" ("Clifford"; see also Spence, Lady Anne Clifford, chs. 7 and 8; Williamson 207; and Lewalski, who argues that Clifford "ruled her domain as a (usually benevolent) autocrat" [130]). Instead of promoting certain elite women writers as individualist protofeminists or as idealized feudal barons, I return not only to some of the insights of Marxist feminism-strangely lost in recent scholarship on Clifford-but also to an interrogation of the feminism we are now heralding and the Renaissance (and implicit medieval-Renaissance divide) we might be resurrecting. My point is not to suggest that feudalism was better for women but rather to look at how our celebration of women's power or resistance might elide the historically specific means by which this power was achieved.

9. As on earlier occasions, during this visit to the North, Clifford rides into "Whinfield Park" as a sign of possession, but this economic "willing" that the tenants keep their money is her first overt resistance to her uncle's rights to the land. It is also here that we see the beginnings of her baronial management of the Westmorland tenants, whom she increasingly refers to as "my folks" (57). This proprietariness is similar to the way in which another Northern landholding woman, Lady Margaret Hoby, emphatically identifies her Yorkshire tenants as "my workwemen" and "my workmen," highlighting that the land they live on is hers and not her husband's $(81,105,108)$. Not coincidentally, Hoby, like Clifford, goes to great lengths to maintain her rights of inheritance on her mother's (i.e., the Dakins family's) lands in Linton. Hoby too rides publicly with her mother in the "feeldes" and "dales" and receives with her at her parish church (69). Like Clifford, Hoby also maintains close relationships with her cousins. She records on one occasion going with a Dakins cousin, Arthur, into the "closes," or parcels of newly enclosed land (in an area that had worked on a system of open common fields up until 1605 [89]), and riding and reading with him in the estates. Both women, that is, saw their lineal property and rights as something distinct from their marital situation, even as something to be defended against their husbands.

10. Hodgkin differentiates between Clifford's role as an "aristocratic woman" in the first part of her life and her role as an "aristocratic woman" in the second (159). Lamb similarly argues that "Clifford remained a split subject, caught in the contradictions between obedient wife and aristocratic heir" (349). Mary Chan and Nancy E. Wright have helpfully historicized Clifford's "aristocratic" role as that of baronial office.

11. Often these negotiations were fought over and through the body of Clifford and Dorset's child. At a heightened moment of disagreement with her husband over the settlement, Clifford ushers their child into adulthood first by dressing her in a "Whalebone bodice," cutting off her coat strings and forcing her to stand alone, and then, more important, by riding publicly with her "on the pye bald nagge that came out of Westmorland" $(81,82)$, an emblem of the child's symbolic inheritance of the Westmorland properties. (Clifford also writes to her mother, "My childe your Littelself, is well," indicating her investment in a female lineage [qtd. in Lewalski 136n50]). When her husband cancels her marital jointure in 1617 (84), Clifford makes it clear that while she is melancholy, "fearing my Lord cou'd give all his land away from the Child" (87), her lineal inheritance is being secured. The tenants at Brougham Castle, she writes, are "very well effected towards me \& very ill towards" her father's brother and son (84). She also notes that during one of the many periods in which her "Lord" was spending his time "Cocking with the King at Greenwich," he "received the last payment of my portion" (114), highlighting how readily the economies of marriage are subsumed into a husband's frivolous courtly pursuits.

12. Unlike her depiction of her own strategies, Clifford presents her husband's frequent "Cockfighting at the court" as a ruse of (petty) power and as an implicit indictment of Jacobean politics: while he frequently lost money in these games, she notes, his losing "brought him into great grace \& favour with the King" (71; see also 97, where she notes a loss of $£ 400$ on Twelfth Night). Indeed, when the king made his famous speech in the Star Chamber about duels and combats, arguably and partially as a means of gaining control over the rivalries and independent battles of his aristocracy (Peltonen), Clifford notes that "my lord [was] standing by his chair where he talked with him all the while, he being in extraordinary grace $\&$ favour with the King" (71). In an essay on Clifford, Susan Wiseman draws attention to Clifford's marginalia in a history of the court of James I. Beside an unflattering description Clifford wrote "a right description of King James" (Wiseman 217n61).

13. The next day, after the men signed the papers at Dorset House and "did what they could to cut me off from my Right," Clifford writes that she referred her "Cause to God" (74). She also records another occasion on which her "Enemys had the upper hand" (87), indicating the extent to which she saw her battle not only as providential but also as heroic and honorable.

14. Interestingly, Dorset would raise the ire of Buckingham and the king by petitioning the king in 1620 "in protest at the claims to precedence over old-established English 
noblemen by newly created Irish and Scottish peers, and by implication, the inflation of honours and the selling of new titles by Buckingham" (Spence, Lady Anne Clifford 78). Clearly Dorset had his own ideas about aristocratic privilege that the role of court favorite did not address. (Spence makes the point as well that Dorset's fortunes, both economic and courtly, were in decline when he made this move.)

15. When the queen dies, in March 1619, Clifford makes the note that when she heard the news, she herself was in the same bed "where I had the first news of my mother's death." About this time, she adds, "I caused the Book of the Cliffords to be newly copy'd out" (101).

16. Indeed, when her husband searches her closet and expresses his "surprise" at how little money she has, we see the extent to which this separation was true in an economic sense as well.

\section{Works Cited}

Acheson, Katherine O. Introduction. Clifford 1-37.

Berkowitz, David S. Rev. of The Family: Sex and Marriage in England, 1500-1800, by Lawrence Stone. Renaissance Quarterly 32 (1979): 396-403.

Butler, Judith. Antigone's Claim: Kinship between Life and Death. New York: Columbia UP, 2000.

-. "Is Kinship Always Already Heterosexual?" Differences 13.1 (2002): 14-44.

Chan, Mary, and Nancy E. Wright. "Marriage, Identity, and the Pursuit of Property in Seventeenth-Century England: The Cases of Anne Clifford and Elizabeth Wiseman." Women, Property, and the Letters of the Law in Early Modern England. Ed. Wright, Margaret W. Ferguson, and A. R. Buck. Toronto: U of Toronto P, 2004. 162-82.

Clifford, Anne. The Diary of Anne Clifford 1616-1619. A Critical Edition. Ed. Katherine O. Acheson. New York: Garland, 1995.

Crawford, Julie. “'Pleaders, Atturneys, Petitioners and the Like': Margaret Cavendish and the Dramatic Petition." Women Players in England, 1500-1660: Beyond the All-Male Stage. Ed. Pamela Brown and Peter Parolin. Burlington: Ashgate, 2005. 241-60.

Ferguson, Margaret W. "Moderation and Its Discontents: Recent Work on Renaissance Women." Feminist Studies 20 (1994): 349-66.

Gallagher, Catherine. "Embracing the Absolute: The Politics of the Female Subject in Seventeenth-Century England." Genders 1 (1988): 24-39.

Goldberg, Jonathan. Desiring Women Writing: English Renaissance Examples. Stanford: Stanford UP, 1997.

Harris, Olivia. "Households and Their Boundaries." History Workshop Journal 13 (1982): 143-52.

Hoby, Margaret. Diary of Lady Margaret Hoby, 1599-1605. Ed. Dorothy M. Meads. Boston: Houghton, 1930.
Hodgkin, Katharine. "The Diary of Lady Anne Clifford: A Study of Class and Gender in the SeventeenthCentury." History Workshop Journal 19 (1985): 148-61.

Kelly, Joan. "Did Women Have a Renaissance?" Women, History, and Theory: The Essays of Joan Kelly. Chicago: U of Chicago P, 1984. 19-50.

Kunin, Aaron. "From the Desk of Anne Clifford." English Literary History 71 (2004): 587-608.

Lamb, Mary Ellen. "The Agency of the Split Subject: Lady Anne Clifford and the Uses of Reading." English Literary Renaissance 22 (1992): 347-68.

Lewalski, Barbara. Writing Women in Jacobean England. Cambridge: Harvard UP, 1993.

Lockyer, Roger. Buckingham, the Life and Political Career of George Villiers, First Duke of Buckingham, 15921628. London: Longman, 1981.

Lucey, Michael. The Misfit of the Family: Balzac and the Social Forms of Sexuality. Durham: Duke UP, 2003.

Peltonen, Markku. The Duel in Early Modern England: Civility, Politeness and Honour. Cambridge: Cambridge UP, 2003.

Quilligan, Maureen. Incest and Agency in Elizabeth's England. Philadelphia: U of Pennsylvania P, 2005.

- "Reperiodizing the Renaissance." Renaissance Soc. of Amer. Conference. Renaissance Parc 55 Hotel, San Francisco. 24 Mar. 2006.

Sackville-West, Vita. Introduction. The Diary of Lady Anne Clifford. Ed. Sackville-West. London: Heinemann, 1923. i-lxvi.

Spence, Richard T. "Clifford, Anne, Countess of Pembroke, Dorset, and Montgomery (1590-1676)." Oxford Dictionary of National Biography. 2004. Oxford UP. 30 Aug. $2006<$ http://www.oxforddnb.com/view/article/5641>.

—. Lady Anne Clifford, Countess of Pembroke, Dorset and Montgomery, 1590-1676. Stroud: Sutton, 1997.

Spivak, Gayatri Chakravorty. "Three Women's Texts and a Critique of Imperialism." Critical Inquiry 12 (1985): 243-61.

Stone, Lawrence. The Family, Sex and Marriage in England, 1500-1800. Abr. ed. New York: Harper, 1979.

Traub, Valerie. The Renaissance of Lesbianism in Early Modern England. Cambridge: Cambridge UP, 2002.

Wilcox, Helen. "Private Writing and Public Function: Autobiographical Texts by Renaissance Englishwomen." Gloriana's Face: Women, Public and Private, in the English Renaissance. Ed. S. P. Cerasano and Marion Wynne-Davies. Detroit: Wayne State UP, 1992. 47-62.

Williamson, George C. Lady Anne Clifford, Countess of Dorset, Pembroke and Montgomery, 1590-1676: Her Life, Letters, and Work. Kendal: Wilson, 1923.

Wiseman, Susan. "Knowing Her Place: Anne Clifford and the Politics of Retreat." Textures of Renaissance Knowledge. Ed. Philippa Berry and Margaret TudeauClayton. Manchester: Manchester UP, 2003. 199-221. 